Consiglio Nazionale delle Ricerche
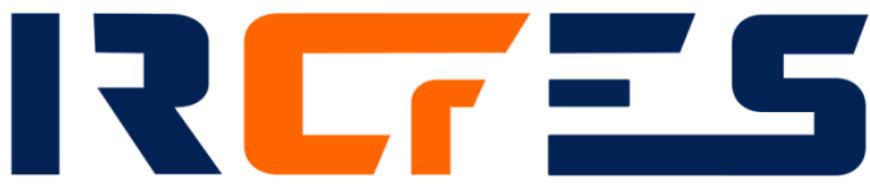

ISTITUTO DI RICERCA SULLA CRESCITA ECONOMICA SOSTENIBILE RESEARCH INSTITUTE ON SUSTAINABLE ECONOMIC GROWTH
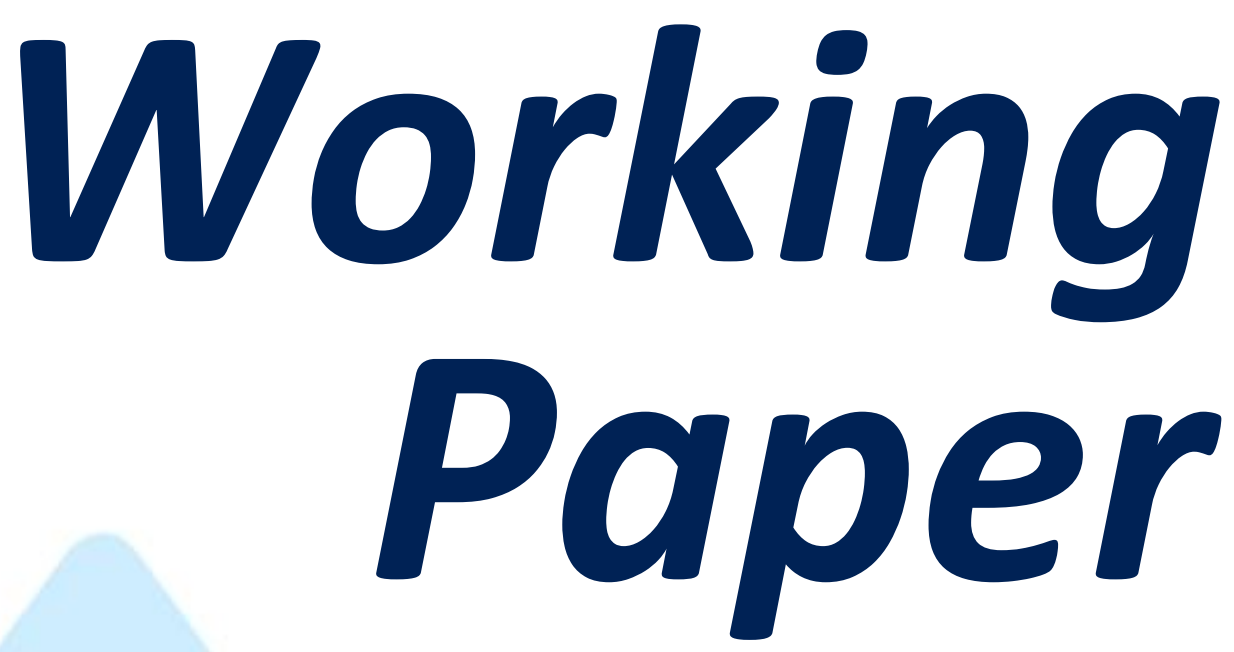

Numero 4/2017

Disruptive technologies and competitive advantage of firms in dynamic markets

Mario Coccia 


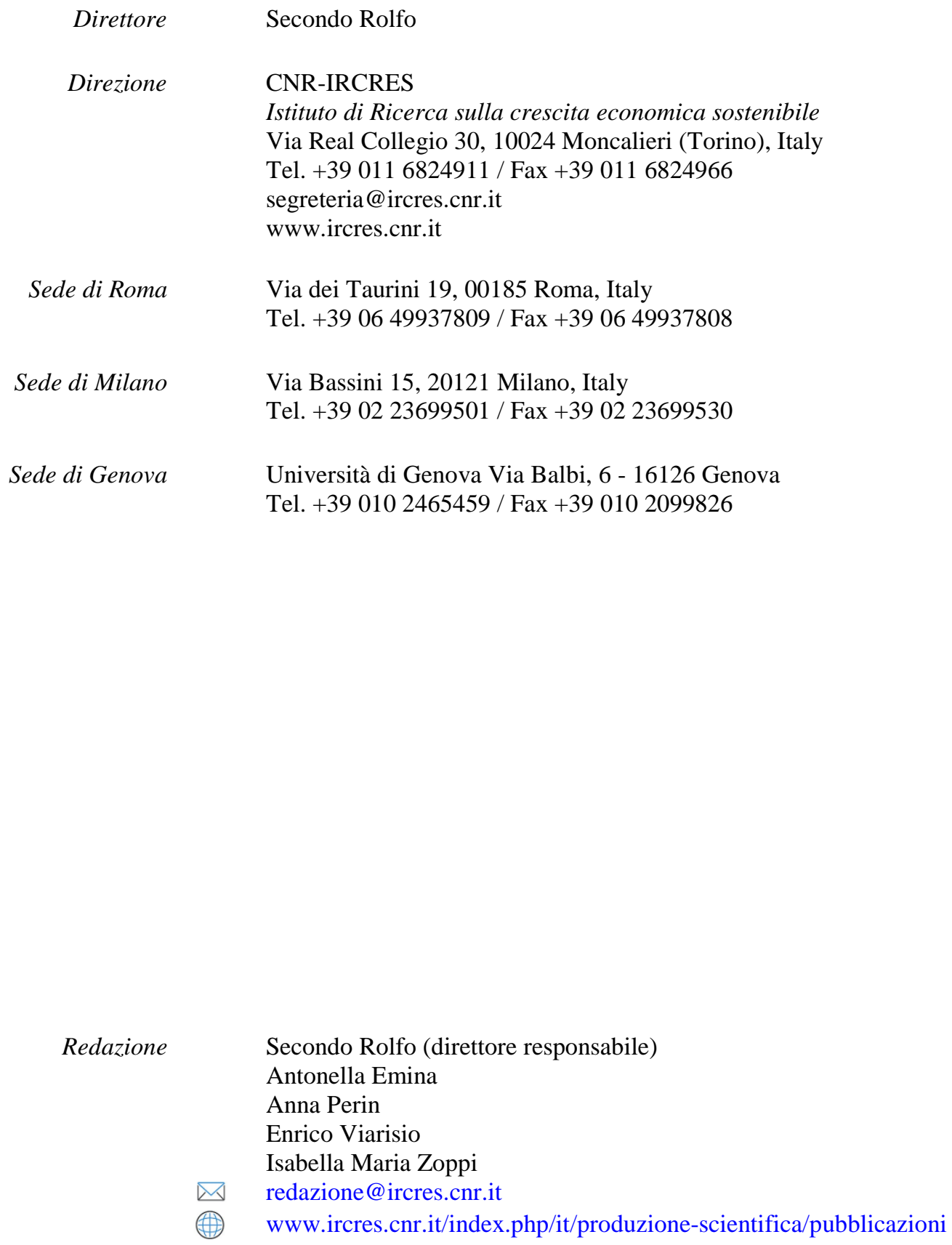

WORKING PAPER CNR-IRCRES, anno 3, numero 4, Aprile 2017

cc) () (9) Copyright (C) Aprile 2017 by CNR - IRCRES 


\title{
Disruptive technologies and competitive advantage of firms in dynamic markets ${ }^{1}$
}

\author{
MARIO COCCIA ${ }^{\text {a, b }}$ \\ ORCID ID: 0000-0003-1957-6731 \\ Country: IT \\ ${ }^{\text {a }}$ CNR-IRCRES, National Research Council, Research Institute on Sustainable Economic Growth, via Real Collegio 30, \\ Moncalieri (TO) - Italy \\ b ARIZONA STATE UNIVERSITY, Center for Social Dynamics \& Complexity, 550 East Orange St., Tempe, Arizona | 85287
}

Mail: mario.coccia@ircres.cnr.it, mario.coccia@cnr.it

\begin{abstract}
A fundamental problem in the field of management of technology is how firms develop and sustain disruptive technologies for competitive advantage in markets. The vast literature has analyzed several characteristics of disruptive innovations. However, the determinants are hardly known. The study here seems to show, in a market with high intensity of R\&D investments (anticancer drugs), that the emergence of disruptive technologies can be driven by the coevolution of consequential problems and their solution in R\&D labs of firms. In general, incumbent and entrant firms have a strong incentive to find innovative solutions to unsolved, consequential and new problems in order to achieve and sustain the prospect of a (temporary) profit monopoly and competitive advantage in markets with technological dynamisms. Overall, then this study shows one of the general sources of disruptive technologies that seems to support industrial and corporate change in a Schumpeterian world of innovation-based competition.
\end{abstract}

\section{KEYWORDS}

Disruptive Technologies; Problem Solving; R\&D Management, Industrial Change, Target Therapy, Anticancer Drugs.

\section{JEL CODES:}

O30, O32

Reference to this paper should be made as follows:

Coccia M. (2017) "Disruptive technologies and competitive advantage of firms in dynamic markets", Working Paper CNR-IRCRES, vol. 3, n. 4, pp. 1-22, ISSN (on line): 2421-7158.

DOI: $10.23760 / 2421-7158.2017 .004$

${ }^{1}$ This research started in 2014 at Arizona State University while I am a visiting scholar funded by National Research Council of Italy. This paper benefited from helpful comments and suggestions by Christopher S. Hayter and an anonymous referee. The author declares that he has no relevant or material financial interests that relate to the research discussed in this paper. 


\section{CONTENTS}

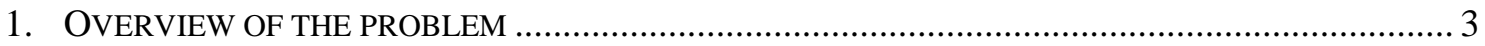

2. THEORETICAL FRAMEWORK AND WORKING HYPOTHESES...................................................... 4

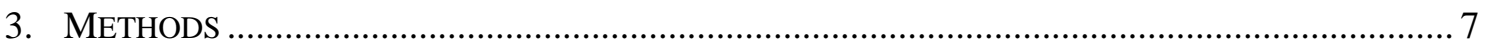

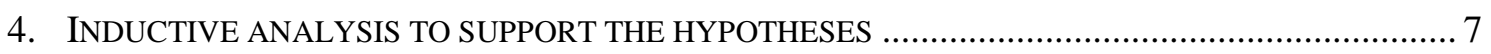

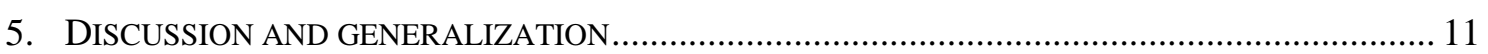

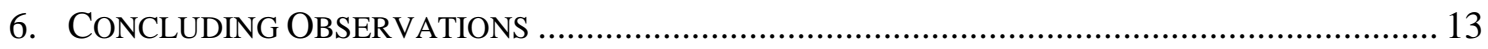

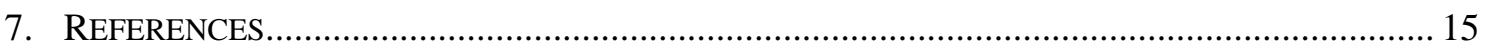




\title{
Disruptive technologies and competitive advantage of firms in dynamic markets
}

\author{
MARIO COCCIA
}

\section{OVERVIEW OF THE PROBLEM}

This article has two goals. The first is to explain how firms develop and sustain disruptive innovations. The second is to show the strategic change ${ }^{1}$ of $R \& D$ management for supporting disruptive technologies and competitive advantage in drug discovery industry.

Management studies have a considerable interest in studying disruptive innovations ${ }^{2}$ because they can explain how firms achieve and sustain competitive advantage in markets (Teece et al., 1997; Chesbrough and Rosenbloom, 2002; Gilbert and Bower, 2002; Danneels, 2006; Jenkins, 2010; King and Baatartogtokh, 2015; Garud et al., 2015; cf., Coccia, 2005a, 2005b, 2006) ${ }^{3}$. The research field of disruptive innovations analyses different characteristics, such as the meaning of disruptive technology (Christensen et al., 2015; Tellis, 2006), technological challenges of incumbent firms (Christensen, 1997, 2006; Danneels, 2004; Hill and Rothaermel, 2003; Ansari et al., 2016; Wessel and Christensen, 2012), market of technology (Arora et al., 2001), leadership effects on innovative activity of firms (Ryan and Tipu, 2013), organizational networks (Garud et al., 2002), etc.

However, the sources of disruptive innovations among different industries are hardly known. In this research domain, critical research questions for management of technology are: what is a vital driver of disruptive innovations in firms? And how R\&D management support the development of disruptive technologies in industries with high intensity of research investments? With respect to these questions, the study here endeavours to explain one of contributing factors that supports disruptive technologies of firms operating into the market of new anticancer treatments. The findings can provide an integrative approach within current theoretical framework of disruptive technologies that can advance our understanding of the sources of disruptive innovation and related $R \& D$ management implications. In order to position this study in existing approaches, the paper begins by reviewing some accepted frameworks for analyzing the sources of disruptive innovation in drug discovery industry.

\footnotetext{
${ }^{1}$ Gioia and Chittipeddi, 1991.

2 Disruptive technology is a concept similar to radical innovations, technological paradigms, technological regimes or path-breaking technologies analyzed in economics of innovation (Freeman and Soete, 1987, p. 56ff; Dosi, 1988; Nelson and Winter, 1982). The study here uses these terms in interchangeable way.

3 See also Coccia and Wang, 2016; Coccia, 2009c, 2015c, 2017; and for environments and science that support innovation $c f$., Coccia, 2005c, 2008c, 2009d, 2010, 2011, 2010a, 2010b, 2010c, 2010d, 2013a, 2014c, 2014d, 2014e, 2015a, Coccia and Bozeman, 2016: Coccia and Wang, 2016; Coccia and Rolfo, 2000, 2002; Rolfo and Coccia, 2005.
} 


\section{THEORETICAL FRAMEWORK AND WORKING HYPOTHESES}

Christensen et al. (2015) argue that disruptive innovations are generated by small firms with fewer resources that successfully challenge established incumbent businesses. In particular, incumbents focus on improving their products and services for markets (usually most profitable), whereas entrants endeavour to develop disruptive technologies in some market segments, delivering the market performance that incumbents' mainstream customers require (Christensen et al., 2015; Christensen, 1997; Calabrese et al., 2005). Firms, generating path-breaking innovations, grow more rapidly than other ones (Tushman and Anderson, 1986, p. 439). Christensen's (1997) approach also argues that disruptive innovations generate significant shifts in markets ( $c f$. ., Henderson, 2006). In general, the technological and market shifts embody competencedestroying and competence-enhancing because some firms can either destroy or enhance the competence existing in an industry (cf., Hill and Rothaermel, 2003; Tushman and Anderson, 1986). In this context, management studies focus on the concept of ambidexterity: the organizational behaviour to simultaneously engage in exploratory and exploitative activities that support both incremental and radical innovations. As a matter of fact, new firms tend to generate competence-destroying discontinuities that increase the environmental turbulence, whereas incumbents focus mainly on competence-enhancing discontinuities that decrease this turbulence. Competence-destroying and competence-enhancing can be due to an ambidexterity behaviour of some firms that simultaneously engage in exploratory and exploitative activities to support incremental and radical innovations (O’Reilly and Tushman, 2004, 2008; Lin and McDonough III, 2014; Durisin and Todorova, 2012) ${ }^{4}$. Some studies argue that the ability of incumbents to develop and to market disruptive innovations is due to their specific ambidexterity (Danneels, 2006; cf., Henderson, 2006). In this R\&D management, a main role is also played by "forwardlooking executives seeking to pioneer radical or disruptive innovations while pursuing incremental gains” (O’Reilly III and Tushman, 2004, p. 76). Disruptive innovation and its development are also due to organizational learning, which is a fundamental strategic process for competitive advantage of firms (Vera and Crossan, 2004). Moreover, managers with strategic leadership within firms play a vital for innovation processes because they inspire others with their vision, create excitement in groups and provide incentives for achieving goals in competitive environments (Bass and Avolio, 1990).

In general, disruptive innovations generate main effects both for consumers and producers in markets and society during the process of diffusion (Markides, 2006, pp.22-23; Markides and Geroski, 2005; O'Neill et al., 1998). In general, disruptive innovations change habits of consumers in markets and undermine the competences and complementary assets of existing producers. Calvano (2007) argues that: "we highlight the role of destruction rather than creation in driving innovative activity. The formal analysis shows that destructive creation unambiguously leads to higher profits whatever the innovation cost” (cf., Tripsas, 1997). In particular, disruptive innovations disturb the business models of incumbents that have to counter mobilize resources to sustain their competitive advantage in the presence of market change (Garud et al., 2002; Markman and Waldron, 2014). Moreover, disruptive innovation speed is also important to a firm's creating and sustaining competitive advantage amidst rapidly changing business environments. Kessler and Chakrabarti (1996, p. 1143) argue that the "innovation speed (a) is most appropriate in environments characterized by competitive intensity, technological and market dynamism, and low regulatory restrictiveness; (b) can be positively or negatively affected by strategic-orientation factors and organizational-capability factors; and (c) has an influence on development costs, product quality, and ultimately project success". These characteristics of new radical technological regimes in markets require that incumbents undertake specific R\&D investments and strategies (Christensen and Raynor, 2003). Although the literature has focused on in-house R\&D investments (e.g., Chesbrough and Rosenbloom, 2002; Henderson and Clark, 1990; Tripsas and Gavetti, 2000), incumbents increasingly build research alliances to increase the access to external knowledge from new firms and/or research organizations (i.e., universi-

\footnotetext{
${ }^{4}$ cf., Coccia, 2016; 2014b; Coccia and Wang, 2015
} 
ties, research institutes; $c f$. , Nicholls-Nixon and Woo, 2003; Coccia, 2014b; Cariola and Coccia, 2004).

A sector with several disruptive innovations is the pharmaceutical industry because of revolution of molecular biology and nanotechnology in diagnostics and therapeutics (Coccia, 2012, 2012b, 2012c, 2013, 2014, 2014a, 2015; Coccia et al., 2012). In this specific industry, gene therapy is a new technological regime emerged during the 1990s that represents a disruptive technology directed to personalized medicine and treatments with higher effectiveness for patients (Wilson, 2012). Kapoor and Klueter (2015) explore some new therapeutic approaches and show that the commercialization of both monoclonal antibodies and gene therapy required that incumbent firms had access to specialized complementary assets such as capabilities in clinical development, relationships with health care service providers and sales teams (cf., Gershon, 1998). Kapoor and Klueter (2015) also argue that incumbents tend to not invest in disruptive technological regimes and maintain a competence-enhancing approach. However, current wave of research alliances and acquisitions in this industry may help incumbents to overcome this "inertia" both in the initial stage of research and in the later stage of development. Other studies show that R\&D investments of innovative enterprises in pharmaceutical industry are directed towards both internal research units and strategic alliances to accelerate the drug discovery process (Coccia, 2005; 2007; 2008a; 2008b; 2009; 2012d; 2014b, 2016, 2016a, 2016b; cf. Coccia et al., 2012).

Theoretical framework of disruptive technologies suffers of some limitations such as the ambiguity in the definition of disruptive innovations that considers technologies but also products and business models (cf., Tellis, 2006; Christensen and Raynor, 2003). Strictly speaking, a disruptive technological innovation is fundamentally a different phenomenon from a disruptive business-model innovation. Disruptive innovations arise in different ways, have different competitive effects, and require different responses from organizational behavior of incumbents and entrants (Markides, 2006, p. 19). These factors are due to a variation in the sources of innovation such as in some industries, innovation users develop innovation, in others most innovations are due to suppliers of innovation-related components and product manufactures (von Hippel, 1988). This variation in the sources of innovation is related to "functional source of innovation ....functional relationship through which they [firms and individuals] derive benefit from a given product, process, or service innovation” (von Hippel, 1988, p. 3, original italics). The understanding of determinants of such variation is important to predict and manage major and minor innovation processes of firms. A vital factor in the development of innovations is also played by the coevolution of technical and institutional events (Van de Ven and Garud, 1994). In the context of basic sources of innovative activities, Usher (1954) proposed a theoretical framework, based on Gestalt psychology, with four main concepts that can explain the emergence and evolution of new technology:

1. Perception of the problem: an incomplete pattern in need of resolution is recognized.

2. Setting stage: assimilation of data related to the problem.

3. Act of insight: a mental act finds a solution to the problem.

4. Critical revision: overall exploration and revision of the problem and improvements by means of new acts of insight.

This theory focuses on accumulation of knowledge and acts of insight that are basic to solve technological problems and develop new technology. Alexander (1964, pp. 15-16) also showed the role of problem solving for new processes of design: "Every design problem begins with an effort to achieve fitness between two entities: the form in question and its context. The form is the solution to the problem; the context defines the problem. In other words, when we speak of design, the real objet of discussion is not the form alone, but the ensemble comprising the form and its context” (cf., Kruger and Cross, 2006; Möhrle and Pannenbäcker, 1997). Dosi (1988, original emphasis) also argued that technological paradigm in markets can be due to solutions of selected technological problems (cf., Coccia, 2014b; 2016). The theoretical linkage between 
problems and their solutions is also emphasized by Popper (1959) in the philosophical analysis of the process of scientific discovery (cf., Lai, 1989, p. 363).

Although scholars recognize that there are different and contextual determinants of pathbreaking innovations, in management there has not been a substantial effort to define a common factor, a prime mover, among major and minor innovations (cf., Dosi, 1988; Christensen, 1997; Christensen et al., 2015; Coccia, 2012) ${ }^{5}$. In fact, a theory of innovation is supposed to explain the determinants of minor and major technological breakthroughs in markets, such as the drivers of disruptive innovations. The theoretical frameworks just discussed suggest a general relation between relevant problems and emergence of disruptive technologies that deserve to be explored.

Suppose that:

- disruptive technologies are major innovations that make prior technical knowledge obsolete and sustain industrial and corporate change.

- there exists, at a given time, a relevant problem/need unresolved for consumers in markets.

The working hypotheses of the study here are:

HP $\theta$ : Relevant problems/needs and their solutions generate disruptive innovations, ceteris paribus.

$H P \sigma$ : Development of disruptive technologies needs a division of scientific labour in the R\&D function, ceteris paribus.

The principal $H P \theta$, called problem-driven disruptive innovation, is the core of the causal model in Figure 1. Unlike the theoretical framework of disruptive innovation (Christensen, 1997), the model here shows that, in a market with high intensity of $R \& D$ investments, the emergence of disruptive innovation $A$ can be driven by the coevolution of relevant problems and their solution in R\&D labs of incumbent firms $\phi$, but a small (entrant) firm $\varepsilon$ can generate a major technological breakthrough $B$ by solving a consequential problem of previous (disruptive) technology. This new technological shift triggers a competitive reaction of incumbent $\phi$ with a new major innovation $B$ ' (similar to $B$ ).

Figure 1: Disruptive innovation driven by consequential problems in an industry with high intensity of R\&D investments.

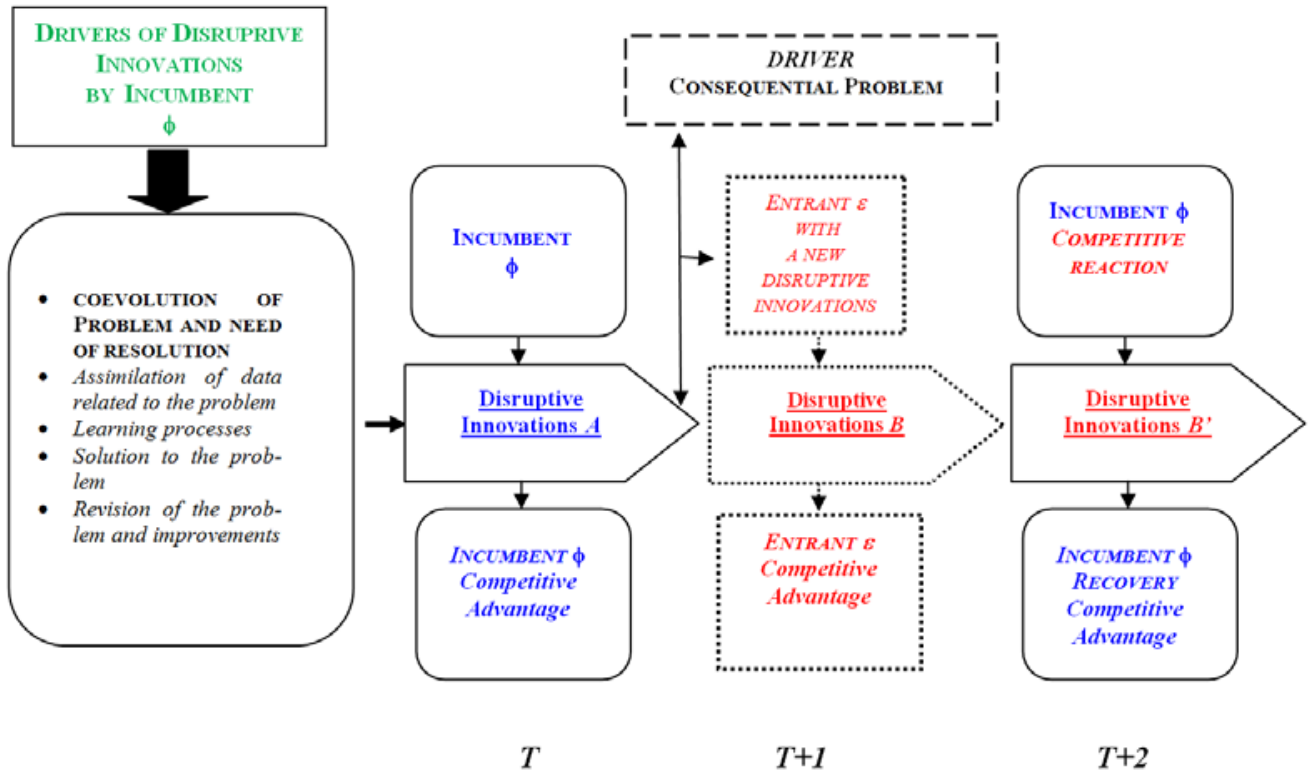

${ }^{5}$ Cf. also Cavallo et al., 2014, 2014a, 2015; Coccia, 2004. 


\section{METHODS}

This study hypothesizes that relevant problems and their solutions in R\&D labs of firms having a division of scientific labour can support the emergence and development of disruptive technologies, ceteris paribus (fig.1). The methodology to support the hypotheses is an inductive study of case study research to explain one of causing factors of disruptive innovations and R\&D management implications (Eisenhardt, 1989; Eisenhardt and Graebner, 2007). In particular, the study here focuses on new target therapies for lung cancer that are generating a paradigm shift in anticancer treatments because of new biopharmaceuticals and small-molecules originated by a convergence of genetics, genomics and proteomics (cf. Coccia, 2012c; 2012e; 2012f, 2015b, 2016a, 2016b; cf., Coccia, 2012g).

The study analyzes three multinational health-care enterprises (incumbents) and a new small firm (entrant) that produce this specific type of disruptive innovations in the market of anticancer treatments. In particular, incumbents in this specific market are:

- AstraZeneca (AZ) is a an British-Swedish research-based biopharmaceutical company based on Astra AB formed in 1913 (Sweden) and British Zeneca Group formed in 1993; Astra AB merged with Zeneca group to form AstraZeneca in 1999.

- Roche is a Swiss multinational health-care company founded in 1896.

- Boehringer Ingelheim (Germany) founded in 1885. It is one of leading pharmaceutical companies worldwide.

The entrant firm is:

- Clovis oncology, a small US pharmaceutical company founded in 2009.

Firstly, the study analyzes shortly the organizational structure of these firms (revenue, operating income, total assets, number of employees and $R \& D$ process) considering last data available from annual reports. Secondly, the study focuses on innovation process that has driven the development of disruptive innovations for lung cancer treatments and the underlying R\&D management. The period under study is from 2009 onwards.

Expected evidence of the inductive study here is to instantiate the hypotheses that disruptive innovations are mainly driven by coevolution of relevant problems and their solution within R\&D laboratories with a division of scientific labour. Findings may also have the potential to clarify one of the general and basic sources of disruptive technologies across several industries in regimes of rapid change.

\section{INDUCTIVE ANALYSIS TO SUPPORT THE HYPOTHESES}

Human and economic resources, and R\&D strategy to support disruptive innovations.

AstraZeneca (AZ)

AstraZeneca is a company that has a net income of US\$2.825 billion (AstraZeneca, 2015b), total assets for US\$60.12 billion (Forbes, 2016) and total number of employees for about 50,000 (AstraZeneca, 2015). The human and economic resources invested in R\&D by AstraZeneca are about 15,000 units of personnel and over US\$4 billion in eight countries (AstraZeneca, 2015).

The discovery phase in AZ is about 4 years to find potential drugs through laboratory research; the development phase is 7 years based on: phase I (small group of volunteers to understand potential new drugs); phase II (small group of patients to evaluate the effectiveness of the medicine); phase III (large group of patients to gather information about effectiveness and safety) and regulatory submission to seek approval from regulatory authorities; post lunch delivering to patients is about 10 years. In short, the length of time of the drug discovery process is roughly 20 years (AstraZeneca, 2015a). AstraZeneca (AZ) to be continually at the forefront of ground-breaking research into human disease has strategic partnerships with organizations to complement in-house technological and scientific capabilities. In particular, AZ builds and reinforces the scientific capabilities by strategic alliances with external sources of innovation: part- 
nership with academic institutions, bio-techs and other pharmaceutical companies to share skills, knowledge and resources through all phases of the R\&D process described above. In addition, the acquisition of the biotechnology firm MedImmune has improved and enlarged the R\&D function and technological capabilities (AstraZeneca, 2015, 2015a).

Roche

Roche is a Swiss multinational health-care company that has an operating income of US\$ 13,852 billion, profit of US\$ 9,374 billion, total assets of US\$ 46,475 billion and number of employees of 88,509 (Roche, 2015a). The resources in R\&D are based on over 18,000 researchers worldwide and about US $\$ 10.6$ billion of investments. R\&D processes in Roche are represented by research and early development (target selection; lead generation); clinical development; commercialization. New products need over 12 years from first discovery. In general, the value chain of the $R \& D$ process to support one innovative drug is driven by roughly: US\$1,058,249,692.118 of R\&D Investment; 7,000,874 Hours of work; 6587 Experiments; 423 Researchers (Roche, 2015). Moreover, Roche, in order to support the drug discoveries in converging genetics, genomics and proteomics, is also an active partnering organization with more than $30 \%$ of research projects in the pipeline that have been carried out with strategic alliances. Roche has a dynamic role to transform key partnerships into strategic alliances. R\&D function is also reinforced by academic partnerships that seek to propel progress in translational medicine and by the subsidiary Genentech in biotechnology (Roche, 2015).

\section{Boehringer Ingelheim (Germany)}

The Boehringer Ingelheim group has an operating income of US\$2,259,932,251, total assets of US\$ 21,173,123,292.01 and number of employees of 47,744. The R\&D human resources are more than 7000 highly qualified people (Boehringer-Ingelheim, 2015).

The drug discovery process is based on the following steps: research (target identification and validation; assay development; lead identification; lead optimization; pre-development); development (preclinical development, clinical research); registration (regulatory approval); and life cycle management. From initial discovery to a marketable medicine is a long process requiring about 12-15 years and an investment of about US\$1 billion (Boehringer-Ingelheim, 2015). Boehringer Ingelheim also supports the in-house R\&D activity with several partnerships with academic institutions, start-up companies and biotechnological enterprises. New alliances have formed with leading companies in biotechnology, such as Abbott Laboratories, Glaxo Wellcome, Pfizer and Eli Lilly. A strategic acquisition is the micro-technology company STEAG microParts $\mathrm{GmbH}$. These strong alliance management functions at Boehringer Ingelheim ensure high-level commitment to successful execution of partnerships directed to innovative products (Boehringer-Ingelheim, 2015).

Mortality of lung cancer: a relevant problem as determinant of new disruptive innovations.

Lung cancer is the most common cause of death from cancer worldwide with the highest mortality: 19.7 \% in age-standardized rate (Mortality ASR W per 100,000 person per year is the rate that a population would have if it had a standard age structure. Standardization is necessary when comparing several populations that differ with respect to age because age has a powerful influence on the risk of cancer, GLOBOCAN, 2012, 2012a). Lung cancer can be either small cell lung cancer or non-small cell lung cancer (NSCLC), with the latter representing about 8090\% of cases (Coccia, 2012a, 2014). Current anticancer treatments for advanced non-small cell lung cancer (NSCLC) are mainly based on chemotherapy agents (such as cisplatin and gemcitabine; carboplatin and paclitaxel, and so on). However, this technology has low efficacy for treating lung cancer since the mortality rate is still high (cf. Ferlay et al., 2013).

Public and private R\&D investments have generated scientific advances in Genetics (the study of the molecular structure and function of genes in the context of a cell or organism), Genomics (a discipline in genetics that studies the genomes of organisms and determines the entire 
Figure 2. The domain of disruptive technologies for anticancer treatments

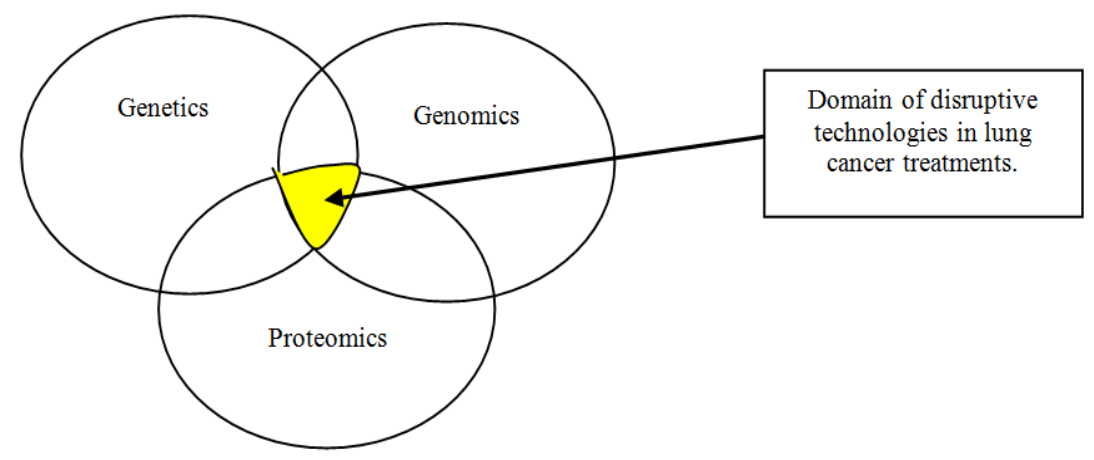

DNA sequence of organisms and fine-scale genetic mapping efforts) and proteomics (the systematic analysis of protein profiles of tissues and parallels the related field of genomics; Coccia, 2012c).

In particular, studies in molecular biology have shown that cancer cells display selfsufficiency of growth signals through the accumulation of genetic and epigenetic changes (e.g., Epidermal Growth Factor: EGF). The EGF acts by binding with high affinity to the Epidermal Growth Factor Receptor (EGF-R) on the cell surface and by stimulating the intrinsic proteintyrosine kinase activity of the receptor, which ultimately leads to cancer cell proliferation (Coccia, 2012a). In order to solve this problem, firms -in this innovation-based market- have a primary incentive to find innovative solutions (e.g., new anticancer drugs) in order to achieve and sustain the prospect of a (temporary) profit monopoly (cf., Madsen and Leiblein, 2015). In particular, the convergence of genetics, genomics and proteomics (Figure 2) has laid the foundations for solution of the problem of lung cancer by developing disruptive technological innovations of target therapies: "drugs or other substances that block the growth and spread of cancer by interfering with specific molecules involved in tumor growth and progression” (as defined by National Cancer Institute, 2015; Coccia, 2012).

Incumbent firms and disruptive innovations in anticancer treatments: target therapies for lung cancer.

Incumbent firms in target therapies for lung cancer are three: AstraZeneca (AZ, SwedenEngland), Roche (Switzerland) and Boehringer Ingelheim (Germany). In order to solve the problem just mentioned above, $\mathrm{R} \& \mathrm{D}$ labs have generated two main radical innovations to treat NSCLC are: Iressa ${ }^{\circledR}$ (based on the blocking agent Gefitinib) by AstraZeneca Company and Tarceva ${ }^{\circledR}$ (based on the blocking agent Erlotinib) commercialized by the Roche. These pathbreaking anticancer drugs are generating a revolution in therapeutic treatments of NSCLC with EGF-R because they block specific enzymes and growth factor receptors involved in cancer cell proliferation (Mitsudomi, 2010, pp. 101-102; Laack et al., 2010). Boehringer-Ingelheim company (Germany), to solve the problems mentioned above and angiogenesis (growth of blood vessels feeding tumors), has also generated innovative target therapies for lung (and other) cancer, commercialized roughly from 2014 onwards, based on multi-inhibitor blocking agents such as nintedanib (triple angiokinase inhibitor) and afatinib dimaleate -commercial name Gilotrif.

Consequential problems for technological development of new disruptive technologies.

Although these disruptive innovations, the incidence and mortality of lung cancer have still high rates (GLOBOCAN, 2012, 2012a). Studies in the biology of the cancer show that it can become resistant to these new drugs ( $c f$. Lovly et al., 2015). In particular, approximately 60 percent of patients typically relapse within 1-3 years of treatment because of drug resistance to tar- 
get therapies described above. In particular, drug resistance of lung cancer is due to the emergence of a consequential problem: a secondary mutation (T790M) that generates a progression of the cancer with several metastases and, as a consequence, high mortality within five years (Coccia, 2012a).

$\square \quad$ Entrant firm to solve the consequential problem with new a disruptive technology.

Clovis Oncology is a small pharmaceutical company, which is generating innovative products for new treatments in oncology. Clovis was founded in 2009 and is headquartered in Boulder, Colorado. The company has a market capital of $\$ 1.26$ billion. The current generation of target therapy for lung cancer by AZ, Roche and Boehringer-Ingelheim companies is designed to target wild type EGFR but this cancer can growth because of new mutations as said above. This small pharmaceutical firm, Clovis oncology, has generated a new disruptive innovation to treat EGFR-mutant lung cancer. This target therapy, called Rociletinib, is a novel, oral, targeted covalent (irreversible) inhibitor to selectively target both the initial activating EGFR mutations and the T790M resistance mutation, with an improved toxicity profile (Clovis Oncology, 2015; 2014). The intensive competition in this drug discovery industry with rapid change has induced the biopharmaceutical company AstraZeneca (2015; 2015a) to react by developing a similar anticancer drug. This new path-breaking innovation for mutated EGFR lung cancers is called Tagrisso $^{\mathrm{TM}}$ (AZD9291) and was approved by US Food and Drug Administration in 2015 (AstraZeneca, 2016).

Overall, this case study described above seems in general to be consistent with the hypothesis $\theta$ of problem-driven innovation that the emergence of disruptive technologies can be explained by a coevolution of consequential problems and problem-solving activity in R\&D labs of firms, ceteris paribus. In fact, both incumbent and entrant firms, in innovation-based markets - as in the drug-discovery industry-have the chief incentive to find innovative solutions/products for unsolved problems in order to achieve and sustain the prospective goal of a (temporary) monopoly of profits. The hypothesis of Problem-Driven innovation can explain one of the driving forces of disruptive innovations. In addition, this conceptual framework has also the potential to explain the general source of several major innovations that support the industrial and corporate change.

Figure 3 synthetizes the argument here showing that the sources of disruptive innovations in this specific pharmaceutical markets are due the interaction between consequential problems and their solutions in R\&D labs of incumbents and entrant firm.

Figure 3: Drivers of disruptive technologies and competition incumbent-entrant in drug discovery industry for lung cancer

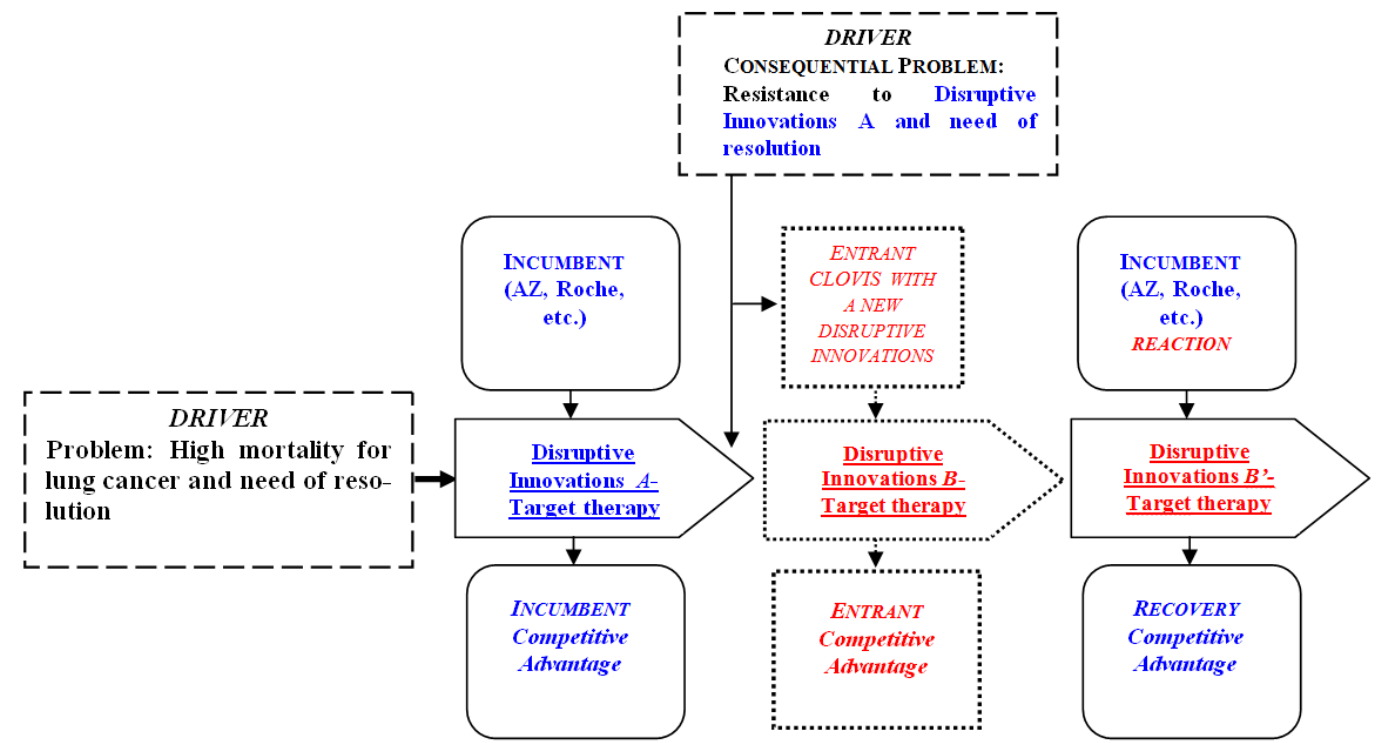


Figure 4: Network of R\&D function of incumbent firms to support disruptive technologies in drug discovery industry.

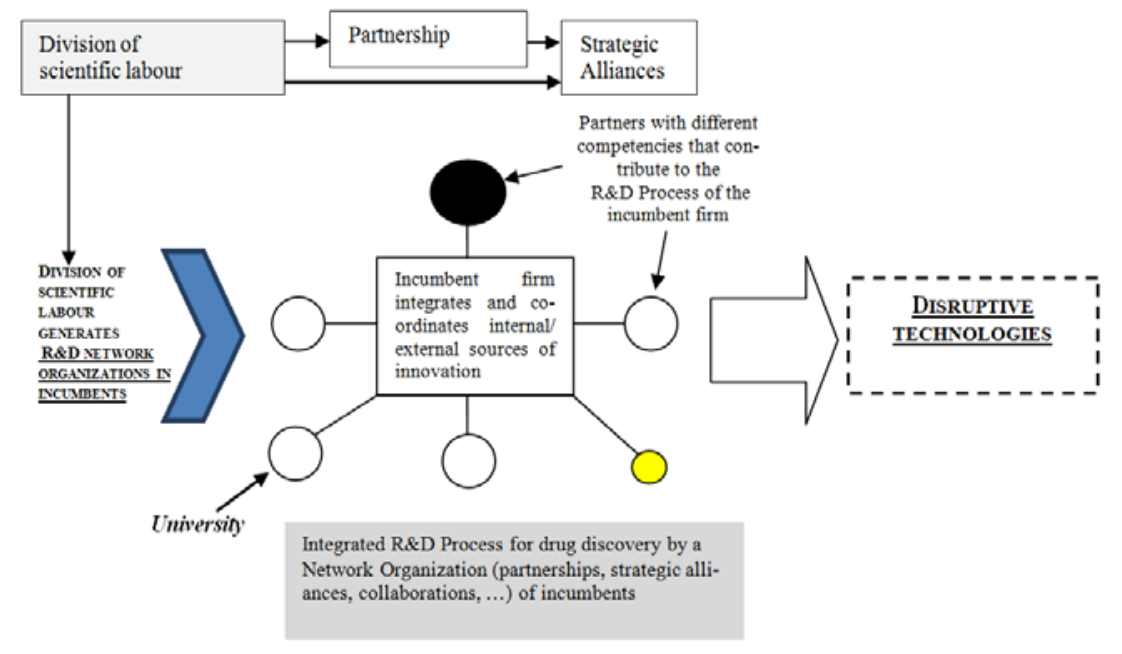

Considering the source of disruptive innovations analyzed above, it has consequences for the organization of R\&D. Von Hippel (1988, p. 9) argued that firms organize R\&D departments that are capable to develop entirely new product development in-house. However, markets in rapid change, such as in drug discovery industry, demand new structures of R\&D to reinforce the integrative capabilities, collective and cumulative learning between in-house R\&D and external sources of innovation (cf., Henderson, 1994). As described above, R\&D strategy of incumbent firms is to create strategic alliances with emerging firms of biotechnology for a division of scientific labour directed to reinforce and accelerate drug discovery process. This R\&D management organizes the R\&D labs with a network structure based on strategic alliances for supporting the discovery process of disruptive innovations (figure 4). This inductive analysis is consistent with the hypothesis $\sigma$.

Overall, then, this study suggests a model that explains one of driving forces of the origin and development of radical-incremental innovations in competitive markets, with a theoretical linkage between emergence of relevant-consequential problems and their solution (i.e., coevolution of innovation with the evolution of consequential problems). One of the primary contributions of this article for both scholars and managers is the strategic role in organizations of an efficient and rapid problem-solving activity. In fact, technical competence and problem-solving activity are crucial for developing several innovations since they translate environmental and organizational inputs into valuable new products and processes (cf. Atuahene-Gima and Wei, 2011, pp. 81-82)

\section{DISCUSSION AND GENERALIZATION}

The theoretical framework of disruptive technologies does not explain the drivers of these path-breaking technologies ( $c f$., Christensen, 1997). The study here endeavours to clarify, whenever possible, one of driving forces of disruptive innovations in drug discovery industry. The evidence, based on a case study research in lung cancer treatments, is consistent with the hypothesis that disruptive technologies are driven by the coevolution of relevant problems and their solutions in a context of scientific division of labor with a network R\&D organization. In particular, findings here suggest a theoretical linkage between relevant-consequential problems and their solution that supports the emergence of disruptive technologies. Main R\&D management implications are the strategic role of efficient and rapid problem-solving R\&D labs of firms in markets with rapid change. This analysis of underlying determinants of disruptive innovations of anticancer drugs is a complex task but it is very important to understand some gen- 
eral driving forces of technological change in markets (Gelijns and Rosenberg, 1994, p. 30ff; 1995; Rosenberg et al., 1995; Coccia, 2012).

In general, firms have goals, such as achieve and sustain competitive advantage (Teece et al., 1997; Coccia, 2014b; 2016a, 2016b) ${ }^{6}$. These vital goals can be supported by disruptive innovations that are highly directional and aimed at solving specific problems. The R\&D process that leads firms in drug discovery industry to solutions of unsolved problems is governed by trial and error (cf., Wagner and Rosen, 2014). Simon (1962, p. 472, original emphasis) claimed that:

\begin{abstract}
The more difficult and novel the problem, the greater is likely to be the amount of trial and error required to find a solution. At the same time, the trial and error is not completely random or blind; it is, in fact, rather highly selective . . . . to see whether they represent progress toward the goal. Indications of progress spur further search in the same direction; lack of progress signals the abandonment of a line of search. Problem solving requires selective trial and error.
\end{abstract}

The central contribution of this work is an approach that integrates current frameworks in management of technology to clarify the sources of disruptive innovations (Dosi, 1988; O’Reilly III and Tushman, 2004; 2008; Cooper 1990). As a matter of fact, the theoretical framework of problem-driven innovation of this study have the potential to be generalized for explaining a basic source of disruptive technologies in several industries. In fact, technical competence and problem-solving activity are crucial factors for developing several innovations since they translate environmental and organizational inputs into valuable new products and processes (cf. Atuahene-Gima and Wei, 2011, pp. 81-82; cf., Van de Ven et al., 2008). Other studies can support the thesis presented in this paper. Ruiz et al. (2012, p. 385ff) argue that new product development depends on accurately identifying problems across consumers and the "problem solving cycle" is a key activity of prototype-driven problem solving in heating products using information of users (Bogers and Horst, 2014, p. 744). Restuccia et al. (2016) analyze the industrial equipment and supply sectors and show that the concept of product-related problems is vital factor for new product development and based on the role of distributors that can support the innovation during the product life-cycle management. Critical problem-solving activity is also present in the semiconductor industry and it is associated with the main variable of speed because in this specific industry, expeditious problem solving is an important performance goal to support technological innovations with short market life cycles (Appleyard et al., 2006). Macher and Mowery (2003), in semiconductor manufacturing, also find that allocating engineering resources to problem-solving activities, associated with information technology and schedule production, influences new process technologies and manufacturing performance.

In general, problem-solving competence is an important factor in firms to develop and sustain disruptive innovations. The approach of problem-driven innovation here seems to be a comprehensive framework with the potential of explaining one of the general sources of disruptive technologies for competitive advantage of firms over time and space. In particular, an efficient innovation management depends on the ability to speed up the activities of solving complex problems in the presence of environmental turbulence (Atuahene-Gima and Wei, 2011).

Another finding of this study is that the emergence of disruptive innovations in drug discovery industry need a R\&D organization more and more based on a division of scientific labour ( $c f$. 'division of innovative labour' by Arora and Gambardella 1995). This strategic change of R\&D labs determines the shifts of the locus of innovations from individual firms (in-house R\&D) to a R\&D network (based on internal/ external source of innovation) by strategic alliances and scientific collaborations across firms to support path-breaking drugs. Network R\&D organizations reinforce the dynamic and sustaining capabilities ${ }^{7}$ of in-house R\&D process by external sources of innovation (partnerships and strategic alliances with public and private labora-

\footnotetext{
${ }^{6}$ For organizational behaviour of public research labs see Coccia 2001, 2008, 2009a, 2009b; Coccia et al., 2015; Coccia and Cadario, 2014; Coccia and Rolfo, 2007, 2010.

${ }^{7}$ Cf., Jenkins (2010); Paruchuri and Eisenman (2012).
} 
tories operating in biotechnology and nanotechnology). In fact, Hage (2011, 53ff) shows that the growth in knowledge and convergence of research fields lead to a differentiation of research organizations and R\&D networks to accelerate drug discovery processes. Overall, then, sources of disruptive innovations, in drug discovery industry, have benefits from linked R\&D organizations that reinforce the cross-fertilization of technological capabilities by the collective and cumulative learning, by the generation of multiplicity of stimuli and by the adoption of different and complementary approaches (cf., Gherardi, 1999).

However, innovations in medicine and other research fields are due to manifold factors. The learning process between clinical research and clinical practice is also a vital factor that supports in this and other research fields the accumulation and advancement of technical knowledge (cf. Gelijns and Rosenberg, 1995, p. 4ff; Gershon, 1998). In fact, the Development phase in medicine, with learning processes based on the interplay between clinical research and clinical practice, supports radical innovations and their improvement (incremental innovation, Gelijns and Rosenberg, 1995). Another factor for the development of innovation is the dynamic capability: "the firm's ability to integrate, build, and reconfigure internal and external competences to address rapidly changing environments" (Teece et al., 1997, p. 516; Helfat et al., 2007, p. 4; Coccia, 2014b). Innovation and its development are also due to organizational learning, which is a fundamental strategic process for competitive advantage of firms (Vera and Crossan, 2004). Moreover, managers with strategic leadership within firms play a vital for innovation processes because they inspire others with their vision, create excitement in groups and provide incentives for achieving goals in competitive environments (Bass and Avolio, 1990). The evolution of new technology can be also due to "inventive analogical transfer" from experience and solutions of consequential problems in one knowledge area-source domain-to other fields - target domains (Kalogerakis et al., 2010, p. 418).

\section{CONCLUDING OBSERVATIONS}

The high mortality rate of lung cancer is a major unsolved problem and is a main impetus for firms in drug discovery industry -characterized by technological and market dynamisms- to develop disruptive technologies of anticancer drugs. On the basis of the argument presented in this paper, based on a case study research, we can therefore conclude that one of principal sources of disruptive innovations is due to a coevolution of consequential problems and related solutions in competitive markets, ceteris paribus. As a matter of fact, the inductive analysis here shows that disruptive innovations of anticancer drugs embody the development of specific technological pathways in a circumscribed problem-solving and learning activity (cf., Dosi, 1988). This process, leading to disruptive innovations, is based on specific dynamic capabilities of firms and previous technological solutions that generate learning processes, a vital cumulative change and path dependence in innovative industries (cf., Garud and Karnøe, 2001; Garud et al., 2010; Teece et al., 1997). These findings seem to be also confirmed by other studies, such as Coccia and Wang (2015, p. 155ff) show that: "the sharp increase of several technological trajectories of anticancer drugs applied by nanotechnology seems to be driven by high rates of mortality of some types of cancers (e.g., pancreatic and brain) in order to find more effective anticancer therapies that increase the progression-free survival of patients". These "technological trajectories mortality driven” are problem-driven by high mortality in pancreatic and brain cancer. In short, relevant and consequential problems seem to be a main and general driving force for disruptive innovations in pharmaceuticals and other industries. In fact, Roche (2015), a multinational health-care company, claims that the research process in medicine has to find: "innovative solutions for serious, currently unsolved medical problems". In short, firms in the drugdiscovery industry have a main incentive to find innovative solutions with new products for unsolved problems in order to achieve the goal of a (temporary) profit monopoly. The hypothesis of problem-driven innovation can explain one of driving forces of several innovations in drug discovery industry and has also the potential to explain one of the general sources of technological paradigms and trajectories that support the technological, industrial and economic change. 
Moreover, case study research here shows that R\&D management has, in drug discovery industry, more and more a division of scientific labour directed to support solutions of relevant problems that may develop disruptive technologies.

In particular,

(1) The conceptual framework here assigns a central role to relevant problems and their solution to explain the origin of disruptive technologies that sustain the industrial and corporate change;

(2) The conceptual framework also shows that disruptive technologies are mainly generated by incumbent firms in sectors at high intensity of R\&D investments. However, small (entrant) firms can generate radical innovations but they have to cope with high economic resources needed for developing the innovations in drug discovery industry (cf., Caner et al., 2016). This financial issue explains the strategic alliances and partnerships between incumbent and entrant firms to develop disruptive and new technologies. A main example is represented by the global collaboration between AstraZeneca and Amgen (a leader in biotechnology) to co-develop and commercialize five monoclonal antibodies from Amgen's clinical portfolio. The collaboration with Amgen is designed to share risk and leverage each partner's functional and geographic strengths. This collaboration improves the expertise of AstraZeneca in respiratory and gastrointestinal diseases, whereas Amgen improves commercial experience in rheumatologic and dermatologic diseases. This collaboration marks a new phase in biopharmaceutical business development of innovations (AstraZeneca, 2015). Moreover, the need of high economic resources to compete in this drug discovery industry -with high intensity of R\&D investments- induces small firms, such as Clovis oncology, to enter in the stock exchange to gather financial resources directed to $R \& D$ of several innovative products in the pipeline.

(3) Finally, the conceptual framework here also shows that the problem-solving activity to generate disruptive innovations in anticancer treatments is based on network R\&D organizations for a division of scientific labor directed to reinforcing the integrative capabilities and collective learning between internal and external sources of innovation.

Overall, then, the conceptual framework here, substantiated in drug discovery industry, has several components of generalization that could easily be extended to explain the source of disruptive technologies across several industries. This study offers important insights to knowledge in these research fields, but the study's findings need to be considered in light of their limitations. In fact, disruptive technologies investigated in this study are a problematic topic due to the diversity across industries and sectors. However, disruptive innovations in this and other industries are due to manifold factors and these results are of course tentative because we know that other things are often not equal over time and space. Especially limiting is the fact that our approach to analysis did not permit some intervening variables that may have been useful in providing a deeper and richer explanation of these phenomena of interests. Hence, much work remains if we are to understand in more depth the reasons for and the implications of disruptive technologies. To conclude, this study provides a preliminary analysis of how firms generate specific disruptive innovations in the presence of technological and market dynamism. More fine-grained studies will be useful in future, ones that can more easily examine other complex predictors of disruptive technologies. Most of the focus here is on a case study research of new anticancer treatments, clearly important but not sufficient for broader understanding of the complex sources of disruptive technologies. In fact, Wright (1997, p. 1562) properly claims: "In the world of technological change, bounded rationality is the rule". 


\section{REFERENCES}

Alexander C., 1964. Notes of the Synthesis of Form, Cambridge (MA), Harvard University Press, pp. 15-16.

Ansari S., Garud R., Kumaraswamy A., 2016. “The disruptor’s dilemma: tivo and the u.s. television ecosystem”, Strategic Management Journal., vol. 37, pp. 1829-1853.

Appleyard M. M., Brown C., Sattler L. 2006. “An international investigation of problemsolving performance in the semiconductor industry", Journal of Product Innovation Management, vol. 23, n. 2, pp. 147-167.

Arora A., Fosfuri A., Gambardella A., 2001. Markets for technology: The economics of innovation and corporate strategy. Cambridge (MA), MIT Press.

Arora A., Gambardella A., 1995. "The division of innovative labour in biotechnology”, in Rosenberg N., Gelijns A.C. and Dawkins H. (Eds.) Sources of medical technology: Universities and industry, ch. 8. Washington (DC), National Academy Press. Inductive

AstraZeneca, 2015. http://www.astrazeneca.com/Research/areas-of-interest (accessed April 2015).

AstraZeneca, 2015a. Openinnovation, http://openinnovation. astrazeneca.com/what-weoffer/compound/azd9291/ [accessed October,1st].

AstraZeneca, 2015b. Annual Report 2015. Retrieved May 2016.

AstraZeneca, 2016. https://www.astrazeneca.com/media-centre/press-releases/2015/TAGRISSO -AZD9291-approved-by-the-US-FDA-for-patients-with-EGFR-T790M-mutation-positivemetastatic-non-small-cell-lung-cancer-13112015.html (accessed December 2016).

Atuahene-Gima K., Wei Y., 2011. "The Vital Role of Problem-Solving Competence in New Product Success", Journal of Product Innovation Management, vol. 28, n. 1, pp. 81-98.

Bass B. M., Avolio B. J., 1990. "The implications of transactional and transformational leadership for individual, team, and organizational development”, in. Staw B. M, Cummings L. L. (Eds.), Research in organizational change and development, vol. 4, pp. 231-272.

Boehringer-Ingelheim, 2015. https://www.boehringer-ingelheim.com/research_development/ drug_discovery/drug_discovery_process.html (accessed April 2015).

Bogers M., Horst W., 2014. "Collaborative prototyping: cross-fertilization of knowledge in prototype-driven problem solving”, Journal of Product Innovation Management, vol. 31, n. 4, pp. 744-764.

Calabrese G., Coccia M., Rolfo S., 2005. "Strategy and market management of new product development: evidence from Italian SMEs”, International Journal of Product Development, vol. 2, n. 1-2, pp. 170-189.

Calvano E., 2007. "Destructive Creation”, SSE/EFI Working Paper Series in Economics and Finance, No 653, December.

Caner T., Bruyaka O., Prescott J. E. 2016. "Flow signals: Evidence from patent and alliance portfolios in the US biopharmaceutical industry", Journal of Management Studies, DOI: $10.1111 /$ joms.12217.

Cariola M., Coccia M. 2004. “Technology transfer virtual network: analysis within the National System of Innovation”, International Journal of Networking and Virtual Organisation, vol. 2, n. 2, pp. 162-172.

Cavallo E., Ferrari E., Bollani L., Coccia M., 2014. "Attitudes and behaviour of adopters of technological innovations in agricultural tractors: A case study in Italian agricultural system”, Agricultural Systems, vol. 130, pp. 44-54.

Cavallo E., Ferrari E., Bollani L., Coccia M., 2014a. "Strategic management implications for the adoption of technological innovations in agricultural tractor: the role of scale factors and environmental attitude”, Technology Analysis \& Strategic Management, vol. 26, n. 7, pp. 765-779.

Cavallo E., Ferrari E., Coccia M., 2015. "Likely technological trajectories in agricultural tractors by analysing innovative attitudes of farmers", International Journal of Technology, Policy and Management, vol. 15, n. 2, pp. 158-177. 
Chesbrough H., Rosenbloom R. S., 2002. "The role of the business model in capturing value from innovation: Evidence from Xerox Corporation's technology spinoff companies”, Industrial and Corporate Change, vol. 11, pp. 529-555.

Christensen C., 1997. The Innovator's Dilemma: When New Technologies Cause Great Firms to Fail. Cambridge (MA), Harvard Business School Press.

Christensen C., 2006. "The ongoing process of building a theory of disruption”, Journal of Product Innovation Management, 23, 39-55.

Christensen C., Raynor M. 2003. The Innovator's Solution. Boston, Harvard Business School Press.

Christensen C., Raynor M. and McDonald R. 2015. "What is disruptive innovation?” Harvard Business Review. December, pp. 44-53.

Clovis Oncology ,2014. Phase 1 evaluation of CO-1686, an irreversible, mutant-selective inhibitor of EGFR mutations (activating and T790M) — Presented at the 4th European Lung Cancer Conference March 2014.

Clovis Oncology, 2015. http://www.clovisoncology.com/products-companion-diagnostics /rociletinib/, accessed February 2015.

Coccia M., 2001. "Satisfaction, work involvement and R\&D performance”, International Journal of Human Resources Development and Management, vol. 1, no. 2/3/4, pp. 268-282.

Coccia M. 2004. "Spatial metrics of the technological transfer: analysis and strategic management”, Technology Analysis \& Strategic Management, vol. 16, n. 1, pp. 31-51.

Coccia M., 2005. "Countrymetrics: valutazione della performance economica e tecnologica dei paesi e posizionamento dell'Italia”, Rivista Internazionale di Scienze Sociali, vol. CXIII, n. 3, pp. 377-412.

Coccia M., 2005a. "Measuring intensity of technological change: the seismic approach", Technological Forecasting and Social Change, vol. 72, No. 2, pp.117-144.

Coccia M., 2005b. “Technometrics: Origins, historical evolution and new direction”, Technological Forecasting \& Social Change, vol. 72, n. 8, pp. 944-979.

Coccia M., 2005c. "Economics of scientific research: origins, nature and structure”, Proceedings of Economic Society of Australia, ISBN: 0734026080.

Coccia M., 2006. "Classifications of innovations: survey and future directions”, Working Paper Ceris CNR, vol. 8, n. 2, pp. 1-19, ISSN (Print): 1591-0709.

Coccia M., 2007. "A new taxonomy of country performance and risk based on economic and technological indicators", Journal of Applied Economics, vol. 10, n. 1, pp. 29-42.

Coccia M., 2008 "New organizational behaviour of public research institutions: Lessons learned from Italian case study", International Journal of Business Innovation and Research, vol. 2, n. 4, pp.402-419.

Coccia M., 2008a. "Investimento pubblico e privato in R\&S: complementarietà ed interazione con la crescita della produttività”, Economia e Politica Industriale, vol. 34, n. 3, pp. 127154.

Coccia M., 2008b. "Science, funding and economic growth: analysis and science policy implications", World Review of Science, Technology and Sustainable Development, vol. 5, n. 1, pp.1-27.

Coccia M., 2008c. "Spatial mobility of knowledge transfer and absorptive capacity: analysis and measurement of the impact within the geoeconomic space", The Journal of Technology Transfer, vol. 33, n. 1, pp. 105-122.

Coccia M., 2009. "What is the optimal rate of R\&D investment to maximize productivity growth?”, Technological Forecasting \& Social Change, vol. 76, n. 3, pp. 433-446.

Coccia M., 2009a. "Bureaucratization in public research institutions", Minerva, A Review of Science, Learning and Policy, vol.47, n. 1, pp. 31-50.

Coccia M., 2009b. "Research performance and bureaucracy within public research labs", Scientometrics, vol. 79, n. 1, pp. 93-107.

Coccia M., 2009c. "Measuring the impact of sustainable technological innovation", International Journal of Technology Intelligence and Planning, vol. 5, n. 3, pp. 276-288. 
Coccia M., 2009d. "A new approach for measuring and analyzing patterns of regional economic growth: empirical analysis in Italy”, Italian Journal of Regional Science-Scienze Regionali, vol. 8, n. 2, pp. 71-95.

Coccia M., 2010. "Democratization is the driving force for technological and economic change”, Technological Forecasting \& Social Change, vol. 77, n. 2, February, pp. 248-264.

Coccia M., 2010a. "Energy metrics for driving competitiveness of countries: Energy weakness magnitude, GDP per barrel and barrels per capita”, Energy Policy, vol. 38, n. 3, pp. 13301339.

Coccia M., 2010b. "Foresight of technological determinants and primary energy resources of future economic long waves”, International Journal of Foresight and Innovation Policy, vol. 6, n. 4, pp. 225-232.

Coccia M., 2010c. "Public and private R\&D investments as complementary inputs for productivity growth", International Journal of Technology, Policy and Management, vol. 10, n. 1/2, pp. 73-91.

Coccia M., 2010d. "Spatial patterns of technology transfer and measurement of its friction in the geo-economic space”, International Journal of Technology Transfer and Commercialisation, vol. 9, n. 3, pp. 255-267.

Coccia M., 2011. "The interaction between public and private R\&D expenditure and national productivity”, Prometheus-Critical Studies in Innovation, vol.29, n.2, pp.121-130.

Coccia M., 2012. Driving forces of technological change in medicine: Radical innovations induced by side effects and their impact on society and healthcare. Technology in Society, vol. 34, n.4, pp. 271-283.

Coccia M., 2012a. Evolutionary growth of knowledge in path-breaking targeted therapies for lung cancer: radical innovations and structure of the new technological paradigm. International Journal of Behavioural and Healthcare Research, vol. 3, ns. 3-4, pp. 273-290.

Coccia M., 2012b. Evolutionary trajectories of the nanotechnology research across worldwide economic players, Technology Analysis \& Strategic Management, vol. 24, n.10, pp. 10291050.

Coccia M., 2012c. Converging genetics, genomics and nanotechnologies for groundbreaking pathways in biomedicine and nanomedicine, Int. J. Healthcare Technology and Management, vol. 13, n. 4, pp. 184-197.

Coccia M., 2012d. "Political economy of R\&D to support the modern competitiveness of nations and determinants of economic optimization and inertia", Technovation, vol. 32, n. 6, pp. 370-379.

Coccia M., 2012e. "Driving forces of technological change in medicine: Radical innovations induced by side effects and their impact on society and healthcare”, Technology in Society, vol. 34, n.4, pp.271-283.

Coccia M. ,2012f. "Evolutionary growth of knowledge in path-breaking targeted therapies for lung cancer: radical innovations and structure of the new technological paradigm", International Journal of Behavioural and Healthcare Research, vol. 3, nos. 3-4, pp. 273-290.

Coccia M., 2012g. "Evolutionary trajectories of the nanotechnology research across worldwide economic players”, Technology Analysis \& Strategic Management, vol. 24, n.10, pp. 10291050.

Coccia M., 2013. The effect of country wealth on incidence of breast cancer. Breast Cancer Research and Treatment, vol. 141, n. 2, pp. 225-229.

Coccia M., 2013a. "What are the likely interactions among innovation, government debt, and employment?”, Innovation: The European Journal of Social Science Research, vol. 26, n. 4, pp. 456-471.

Coccia M., 2014. Path-breaking target therapies for lung cancer and a far-sighted health policy to support clinical and cost effectiveness. Health Policy and Technology, vol. 1, n. 3, pp. 7482.

Coccia M., 2014a. Emerging technological trajectories of tissue engineering and the critical directions in cartilage regenerative medicine. Int. J. Healthcare Technology and Management, vol. 14, n. 3, pp. 194-208. 
Coccia M., 2014b. Converging scientific fields and new technological paradigms as main drivers of the division of scientific labour in drug discovery process: the effects on strategic management of the R\&D corporate change. Technology Analysis \& Strategic Management, vol. 26, n. 7, pp. 733-749.

Coccia M., 2014c. "Driving forces of technological change: The relation between population growth and technological innovation-Analysis of the optimal interaction across countries", Technological Forecasting \& Social Change, vol. 82, n. 2, pp. 52-65.

Coccia M., 2014d. "Socio-cultural origins of the patterns of technological innovation: What is the likely interaction among religious culture, religious plurality and innovation? Towards a theory of socio-cultural drivers of the patterns of technological innovation”, Technology in Society, vol. 36, n. 1, pp. 13-25.

Coccia M., 2014e. "Religious culture, democratisation and patterns of technological innovation”, International Journal of sustainable society, vol. 6, n.4, pp. 397-418.

Coccia M., 2015. The Nexus between technological performances of countries and incidence of cancers in society. Technology in Society, vol. 42, August, pp. 61-70.

Coccia M., 2015a. "Patterns of technological outputs across climate zones: the geography of innovation”, Prometheus. Critical Studies in Innovation, vol. 33, n. 2, pp. 165-186.

Coccia M., 2015b. "The Nexus between technological performances of countries and incidence of cancers in society”, Technology in Society, vol. 42, August, pp. 61-70.

Coccia M., 2015c. "General sources of general purpose technologies in complex societies: Theory of global leadership-driven innovation, warfare and human development", Technology in Society, Volume 42, August 2015, Pages 199-226.

Coccia M., 2016. Radical and incremental innovation problem-driven to support competitive advantage of firms, Technology Analysis \& Strategic Management, DOI: 10.1080/09537325.2016.1268682.

Coccia M., 2016a. "Radical innovations as drivers of breakthroughs: characteristics and properties of the management of technology leading to superior organizational performance in the discovery process of R\&D labs”, Technology Analysis \& Strategic Management, vol. 28, n. 4, pp. 381-395.

Coccia M., 2016b. "Sources of technological innovation: Radical and incremental innovation problem-driven to support competitive advantage of firms”, Technology Analysis \& Strategic Management, DOI: 10.1080/09537325.2016.1268682.

Coccia M., 2017. "The source and nature of general purpose technologies for supporting next K-waves: Global leadership and the case study of the U.S. Navy's Mobile User Objective System”, Technological Forecasting and Social Change, vol. 116, pp. 331-339, DOI: 10.1016/j.techfore.2016.05.019

Coccia M., Bozeman B., 2016. "Allometric models to measure and analyze the evolution of international research collaboration”, Scientometrics, vol. 108, n. 3, pp. 1065-1084.

Coccia M., Cadario E., 2014 "Organisational (un)learning of public research labs in turbulent context”, International Journal of Innovation and Learning, vol. 15, n. 2, pp.115-129.

Coccia M., Falavigna G., Manello A., 2015. "The impact of hybrid public and market-oriented financing mechanisms on scientific portfolio and performances of public research labs: a scientometric analysis”, Scientometrics, vol. 102, n. 1, pp. 151-168.

Coccia M., Finardi U., Margon D., 2012. Current trends in nanotechnology research across worldwide geo-economic players, The Journal of Technology Transfer, vol. 37, n. 5, pp. 777-787, DOI: 10.1007/s10961-011-9219-6.

Coccia M., Rolfo S., 2000. "Ricerca pubblica e trasferimento tecnologico: il caso della regione Piemonte" in Rolfo S. (eds) Innovazione e piccole imprese in Piemonte, Milano (Italy), Franco Angeli Editore, ISBN: 9788846418784.

Coccia M., Rolfo S., 2002. "Technology transfer analysis in the Italian national research council”, Technovation - The international journal of technological innovation and entrepreneurship, vol. 22, n. 5, pp. 291-299. 
Coccia M., Rolfo S., 2007. "How research policy changes can affect the organization and productivity of public research institutes", Journal of Comparative Policy Analysis, Research and Practice, vol. 9, n. 3, pp. 215-233.

Coccia M., Rolfo S., 2010. "New entrepreneurial behaviour of public research organizations: opportunities and threats of technological services supply”, International Journal of Services Technology and Management, vol. 13, n. 1/2, pp. 134-151.

Coccia M., Wang L., 2015. "Path-breaking directions of nanotechnology-based chemotherapy and molecular cancer therapy”, Technological Forecasting and Social Change, vol. 94, May, pp. 155-169.

Coccia M., Wang L., 2015. Path-breaking directions of nanotechnology-based chemotherapy and molecular cancer therapy. Technological Forecasting and Social Change, vol. 94, May, pp. 155-169.

Coccia M., Wang L., 2016. "Evolution and convergence of the patterns of international scientific collaboration”, Proceedings of the National Academy of Sciences of the United States of America, vol. 113, n. 8, pp. 2057-2061.

Cooper R. G., 1990. "Stage-gate systems: a new tool for managing new products”, Business Horizons, vol. 33, n. 3, pp. 44-54.

Danneels E., 2004. "Disruptive technology reconsidered: a critique and research agenda”, Journal of Product Innovation Management, vol. 21, n. 4, pp. 246-258.

Danneels E., 2006. "Dialogue on the effects of disruptive technology on firms and industries", Journal of Product Innovation Management, vol. 23, n. 1, pp. 2-4.

Dosi G., 1988. "Sources procedures and microeconomic effects of innovation”, Journal of Economic Literature, vol. 26, n. 3, pp. 1120-1171.

Durisin B., Todorova G., 2012. "A study of the performativity of the " ambidextrous organizations » theory: neither lost in nor lost before translation", Journal of Product Innovation Management (The), vol. 29, n. S1, pp. 53-75.

Eisenhardt K. M., Graebner M. E., 2007. "Theory Building from cases: opportunities and challenges”, The Academy of Management Review, vol. 50, n. 1, pp. 25-32.

Eisenhardt K.M., 1989. "Building theories from case study research", The Academy of Management Review, vol. 14, n. 4, pp. 532-550.

Ferlay J., Soerjomataram I., Ervik M., Dikshit R., Eser S., Mathers C., Rebelo M., Parkin D.M., Forman D., Bray, F., 2013. GLOBOCAN 2012 v1.0, Cancer Incidence and Mortality Worldwide: IARC CancerBase No. 11 [Internet]. Lyon, France: International Agency for Research on Cancer; 2013. Available from: http://globocan.iarc.fr, accessed on 19/06/2014.

Forbes, 2016. www.forbes.com/companies/astrazeneca/ (accessed November 2016).

Freeman C., Soete L., 1987. Technical change and full employment, Oxford (UK), Basil Blackwell.

Garud R., Jain S., Kumaraswamy A., 2002. “Orchestrating institutional processes for technology sponsorship: the case of Sun Microsystems and Java”, Academy of Management Journal, vol. 45, pp. 196-214.

Garud R., Simpson B., Langley A., Tsoukas H. 2015. (Eds), The Emergence of Novelty in Organizations, Oxford University Press.

Garud R., Karnøe P. (Eds), 2001. Path Dependence and Creation, Mahwah (NJ), Lawrence Erlbaum.

Garud R., Kumaraswamy A., Karnøe P., 2010. “Path dependence or path creation?”, Journal of Management Studies, vol. 47, pp. 760-74.

Gelijns A. C., Rosenberg N. 1994. "The dynamics of technological change in medicine”, Health Affairs, vol. 13, n. 3, pp. 28-46.

Gelijns A. C., Rosenberg N. 1995. "The changing nature of medical technology development”, in Rosenberg N., Gelijns A. C., Dawkins H. (Eds.) Sources of Medical Technology: Universities and Industry; Ch. 1, Washington (DC), National Academy Press.

Gershon E.S., 1998. "Making progress: Does clinical research lead to breakthroughs in basic biomedical sciences?”, Perspectives in Biology and Medicine, vol. 42, n. 1, pp. 95-102. 
Gherardi S., 1999. "Learning as problem driven or learning in the face of mystery", Organization Studies, vol. 20, n. 1, pp. 101-124.

Gilbert C., Bower J. 2002. "Disruptive Change: When Trying Harder Is Part of the Problem”, Harvard Business Review, vol. 80, n. 5, pp. 94-102.

Gioia D. A., Chittipeddi K., 1991. "Sensemaking and sensegiving in strategic change initiation”, Strategic Management Journal, vol. 12, n. 6, pp. 433-448.

GLOBOCAN, 2012. IARC-Section of Cancer Information. Available from http://globocan.iarc.fr/ (accessed 16 /01/2015).

GLOBOCAN, 2012a. IARC. Section of Cancer Surveillance (accessed 17/11/2016).

Hage J., 2011. Restoring the innovative edge, driving the evolution of science and technology, Stanford (CA), Stanford University Press.

Helfat C.E., Finkelstein S., Mitchell W., Peteraf M.A., Singh H., Teece D., Winter S.G., (2007) Dynamic Capabilities: Understanding Change in Organizations, Oxford, Blackwell.

Henderson R. ,2006. “The Innovator's Dilemma as a Problem of Organizational Competence”, J Prod Innov Manag., vol.23, pp. 5-11.

Henderson R., 1994. "The evolution of integrative capability: Innovation in cardiovascular drug discovery”, Industrial and Corporate Change, vol.3, pp. 607-30.

Henderson R. M., Clark K.B., 1990. "Architectural Innovation: The Reconfiguration of Existing Product Technologies and the Failure of Established Firms”, Administrative Science Quarterly, vol. 35, n. 1, pp. 9-30.

Hill C., Rothaermel F., 2003. "The performance of incumbent firms in the face of radical technological innovation”, Academy of Management Review, vol. 28, pp. 257-274.

Jenkins M., 2010. "Technological discontinuities and competitive advantage: a historical perspective on formula 1 motor racing 1950-2006”, Journal of Management Studies, vol. 47, n.5, pp. 884-910.

Kalogerakis K., Lüthje C., Herstatt C., 2010. "Developing innovations based on analogies: experience from design and engineering consultants", Journal of Product Innovation Management, vol. 27, n. 3, pp. 418-436.

Kapoor R., Klueter T., 2015. "Decoding the adaptability-rigidity puzzle: Evidence from pharmaceutical incumbents' pursuit of gene therapy and monoclonal antibodies”, Academy of Management Journal, vol. 58, pp. 1180-1207.

Kessler E. H., Chakrabarti A. K., 1996. "Innovation Speed: A Conceptual Model of Context, Antecedents, and Outcomes”, The Academy of Management Review, vol. 21, n.4, pp. 11431191.

King A., Baatartogtokh B., 2015. "How useful is the theory of disruptive innovation”, MIT Sloan Management Review, vol. 57, pp. 77-90.

Kruger C., Cross N. 2006. "Solution driven versus problem driven design: strategies and outcomes”, Design Studies, vol. 27, pp. 527-548.

Laack E., Sauter G., Bokemeyer C., 2010. "Lessons learnt from gefitinib and erlotinib: key insights into small-molecule EGFR-targeted kinase inhibitors in non-small cell lung cancer”, Lung Cancer, vol. 69, n. 3, pp. 259-264.

Lai T., 1989. "How We Make Discoveries”, Synthese, vol. 79, n.3, pp. 361-392.

Lin H.-E., McDonough III E. F., 2014. "Cognitive frames, learning mechanisms, and innovation ambidexterity”, Journal of Product Innovation Management. vol. 3, n. S1, pp. 170-188.

Lovly C., Horn L., Pao W. ,2015. "EGFR c.2573T>G (L858R) Mutation in Non-Small Cell Lung Cancer”, My Cancer Genome, http://www.mycancergenome.org/content/disease/lungcancer/egfr/5/ (Accessed March 5).

Macher J. T., Mowery D. C., 2003. "Managing learning by doing: an empirical study in semiconductor manufacturing”, Journal of Product Innovation Management, vol. 20, n.5, pp. 391-410.

Madsen T. L., Leiblein M. J., 2015. "What Factors Affect the Persistence of an Innovation Advantage?”, Journal of Management Studies, vol. 52, n. 8, pp. 1097-1127.

Markides C., 2006. "Disruptive innovation: In need of better theory”, Journal of Product Innovation Management, vol. 23, pp. 19-25. 
Markides C., Geroski P., 2005. Fast Second: How Smart Companies Bypass Radical Innovation to Enter and Dominate New Markets. Jossey-Bass, San Francisco.

Markman G. D., Waldron T. L., 2014. "Small entrants and large incumbents: a framework of micro entry”, Academy of Management Perspectives, vol. 28, n. 2, pp. 179-197.

Mitsudomi T., 2010. "Advances in target therapy for lung cancer”, Journal of Clinical Oncology, vol. 40, n. 2, pp. 101-106.

Möhrle M. G., Pannenbäcker, 1997. "Problem-driven inventing: a concept for strong solutions to inventive tasks", Creative and innovation management, vol. 6, n. 4, pp. 234-248.

National Cancer Institute, 2015. http://www.cancer.gov/ (accessed January 2015).

Nelson R. R., Winter S. G., 1982. An Evolutionary Theory of Economic Change, Cambridge (MA), The Belknap Press of Harvard University Press.

Nicholls-Nixon C. L., Woo C. Y., 2003. "Technology sourcing and output of established firms in a regime of encompassing technological change”, Strategic Management Journal, vol. 24. pp. 651-666.

O’Reilly III C. A., Tushman M. L., 2004. “The ambidextrous organization”, Harvard Business Review, vol. 82, n. 4, pp. 74-81.

O’Reilly III C. A., Tushman M. L., 2008. “Ambidexterity as a dynamic capability: Resolving the innovator's dilemma”, Research in Organization Behavior, vol. 28, pp. 185-206.

O'Neill H. M., Pouder R. W., Buchholtz A. K., (1998) "Patterns in the Diffusion of Strategies across Organizations: Insights from the Innovation Diffusion Literature", The Academy of Management Review, vol. 23, n. 1, pp. 98-114.

Paruchuri S., Eisenman M., 2012. "Microfoundations of Firm R\&D Capabilities: A Study of Inventor Networks in a Merger”, Journal of Management Studies, vol. 49, n. 8, pp. 1509-1535.

Popper K., 1959. The Logic of Scientific Discovery, New York, Basic Books.

Restuccia M., De Brentani U., Legoux R., Ouellet J. F., 2016. "Product Life-Cycle Management and Distributor Contribution to New Product Development”, Journal of Product Innovation Management, vol. 33, n. 1, pp. 69-89.

Roche, 2015. http://www.roche.com/research_and_development/who_we_are_how_we_work/ research_process/value_chain.htm (accessed April 2015).

Roche, 2015a. Financial report 2014. Retrieved March 2015.

Rolfo S., Coccia M., 2005. "L'interazione tra ricerca pubblica e industria in Italia”, L'Industria Rivista di Economia e Politica Industriale, vol. 26, n. 4, pp. 657-674.

Rosenberg N., Gelijns A. C., Dawkins H., 1995. Sources of Medical Technology: Universities and Industry. Committee on Technological Innovation in Medicine, Institute of Medicine, Washington (DC), National Academy Press.

Ruiz D., Jain D., Grayson K., 2012. "Subproblem decomposition: an exploratory research method for effective incremental new product development". Journal of Product Innovation Management, vol. 29, n. 3, pp. 385-404.

Ryan J. C., Tipu S. A. A., 2013. "Leadership effects on innovation propensity: A two-factor full range leadership model”, Journal of Business Research, vol. 66, n. 10, pp. 2116-2129.

Simon H. A. 1962. "The Architecture of Complexity", Proceedings of the American Philosophical Society, vol. 106, n. 6, pp. 467-482.

Teece D. J., Pisano G., Shuen A., 1997. "Dynamic capabilities and strategic management”, Strategic Management Journal, vol. 18, n. 7, pp. 509-533.

Tellis G. J., 2006. “Disruptive technology or visionary leadership?”, Journal of Product Innovation Management, vol. 23, pp. 34-38.

Tripsas M., 1997. "Unraveling the process of creative destruction: Complementary assets and incumbent survival in the typesetter industry”, Strategic Management Journal, vol. 18 (Summer Special Issue), pp. 119-142.

Tripsas M., Gavetti G., 2000. "Capabilities, cognition and inertia: Evidence from digital imaging”, Strategic Management Journal, vol. 21, pp. 1147-1161.

Tushman M., Anderson P., 1986. "Technological discontinuities and organizational environments”, Administrative Science Quarterly, vol. 31, n. 3, pp. 439-465. 
Usher A. P., 1954. A history of mechanical inventions, Cambridge (MA), Harvard University Press.

Van de Ven A., Garud R., 1994. The coevolution of technical and institutional events in the development of an innovation. In Baum J. A, Singh J. V (Eds.) Evolutionary dynamics of organizations, New York, Oxford University Press, pp. 425-443.

Van de Ven A., Polley D., Garud R., Venkataraman S., 2008. The Innovation Journey, Oxford University Press.

Vera D., Crossan M., 2004 "Strategic leadership and organizational learning”, The Academy of Management Review, vol. 29, n. 2, pp. 222-240.

Von Hippel E., 1988. The Sources of Innovation, Oxford University Press.

Wagner A., Rosen W., 2014. "Spaces of the possible: universal Darwinism and the wall between technological and biological innovation”, Journal of the Royal Society Interface, vol. 11, pp.1-11.

Wessel M., Christensen C. M., 2012. "Surviving disruption. It's not enough to know that a threat is coming. You need to know whether it's coming right for you", Harvard Business Review vol. 90, n. 12, pp. 56-65.

Wilson J. M., 2012. “It's time for gene therapy to get disruptive!”, Human Gene Therapy, vol. 23, pp. 1-3.

Wright G., 1997. “Towards a more historical approach to technological change”, The Economic Journal, vol. 107, September, pp. 1560-1566. 